\title{
EVALUATION THE ANTIMICROBIAL ACTIVITY OF THYME AND ROSEMARY EXTRACTS AGAINST SOME FOOD RELATED BACTERIA
}

\author{
W. S. Abd El Kader(1), A. A. Sakr(2), Kh. M. Taha(2) and M. M. Abozid(2) \\ (1) Ministry of Health and population \\ (2) Biochemistry department, Faculty of Agriculture, Menofia University.
}

Received: Feb. 15, 2021

Accepted: Apr. 4, 2021

\begin{abstract}
Today, the increased use of antibiotics leads to the incidence of resistant strains. We are faced with lack of new antimicrobial drugs that have fewer side effects than antibiotic. Plants are the main source of secondary metabolites, which can use as natural antimicrobial agents.

In current study, rosemary and thyme were used to determine their chemical composition, phenolic compounds profile (by HPLC) and evaluate the antimicrobial effects against some pathogenic bacteria. Ethanol and acetone extracts of rosemary and thyme leaves (with concentrations of $50,100,200$ and $400 \mathrm{mg} / \mathrm{ml}$ ) were prepared, and antibacterial activities were tested by disc diffusion method on strains of Gram-positive bacteria: Staphylococcus aureus, Bacillus cereus and Streptococcus pyogenes. Gramnegative bacteria: Escherichia coli, Salmonella typhi and Shigella species.
\end{abstract}

The results showed that all the concentrations of ethanolic and acetone rosemary extracts showed the highest level inhibitory zone diameters against Escherichia coli and Bacillus cereus, respectively. While the same extracts recorded the lowest level inhibitory zone against Staphylococcus aureus for both extracts. Similarly, all concentrations of the ethanolic and acetone thyme extracts showed the highest level inhibitory zone diameters against Escherichia coli and Salmonella typhi respectively, while the same extracts recorded the lowest level inhibitory zone diameters against Bacillus cereus and Escherichia coli, respectively.

we can recommend the use of both Thyme and Rosemary as natural antimicrobials agents against food spoilage bacteria to overcome the phenomenon of antibiotics resistance, which represents a serious challenge to humans.

Key words: Thyme, rosemary, pathogenic bacteria, phenolic compounds (HPL).

\section{INTRODUCTION}

Foodborne diseases are caused by agents that enter the body through the ingestion of food. Food can transmit disease from person to person, as well as serve as a growth medium for bacteria that can cause food poisoning. In industrialized countries, the percentage of the population suffering from foodborne diseases each year has been reported to be up to $30 \%$ (WHO, 2007).

An antibiotic was originally defined as a substance produced by one microorganism, which inhibited the growth of other microorganisms. In 2013, the Centers for Disease Control (CDC) in the USA asserted that humanity is now in the "post-antibioticera" (Centers for Disease Control, 2013). Antimicrobial resistance (AMR) within a wide range of infectious agents is growing public health threat of broad concern to countries and multiple sectors. Bacterial drug resistance is a world problem, a high number of bacterial species have become resistant to anti-bacterial drugs (Garau, 1994). The primary cause of 
antibiotic resistance is genetic mutation in bacteria (Laxminarayan, 2003).

Several medicinal plants have been recognized as valuable resources of natural antimicrobial compounds as an alternative that can potentially be effective in the treatment of these problematic bacterial infections (Iwu et al., 1999). According to the World Health Organization (WHO), medicinal plants would be the best source to obtain a variety of drugs (WHO, 2002). Plants are rich in a wide variety of secondary metabolites such as tannins, alkaloids, phenolic compounds, and falvonoids, which have been found to have antimicrobial properties (Djeussi et al., 2013). At present, nearly $30 \%$ or more of the modern pharmacological drugs are derived directly or indirectly from plants and their extracts (Jabeen et al., 2007; Banso, 2009; Ahameethunisa and Hopper, 2010; and Murugesan et al., 2011).

Herbs and spices have most of the antimicrobials derived from plants (Tajkarimi et al., 2010; Cueva et al., 2010; Negi, 2012). These compounds have different structural configurations, having different antimicrobial actions against foodborne pathogens (Savoia, 2012).

Rosemary extracts have been used in food preservation, because they prevent oxidation and microbial contamination (Djenane et al., 2002; Nieto et al., 2010; Nieto et al., 2012). EFSA (European Food Safety Authority) has reviewed the safety of rosemary extracts (Aguilar et al., 2008). Thyme extracts showed high efficiency as natural antimicrobial against several food related bacteria (Boruga et al., 2014; Manconi et al., 2018). The aim of this study is to determine the chemical composition together with the antimicrobial properties of rosemary and thyme extracts, cultivated in Egypt, in order to identify new natural antimicrobials sources with applications in the pharmaceutical and food industry.

\section{MATERIALS AND METHODS}

\section{Materials:}

Plant samples:

The fresh leaves of rosemary (Rosmarinus officinalis) and thyme (Thymus vulgaris) plants were obtained from the Agriculture Research Center in Giza, Egypt. Plants samples were washed and air-dried for 24 hours, then dried at $50^{\circ} \mathrm{C}$. The dried samples were grinded into fine powder and kept in a sterile airtight container.

\section{Bacterial strains:}

Microbial strains were obtained from plant disease department, Agricultural Research Center, Ministry of Agriculture, Giza, Egypt. Gram-positive bacteria: Staphylococcus aureus, Bacillus cereus and Streptococcus pyogenes. Gramnegative bacteria: Escherichia coli, Salmonella typhi and Shigella species.

Culture, Media, Antibiotic and Chemicals:

Muller Hinton Agar (MHA), Gentamycin (30 $\mu \mathrm{g} / \mathrm{disc}$ ), ethanol $95 \%$, acetone $80 \%$, Folin-Ciocalteu reagent, sodium carbonate $\left(\mathrm{Na}_{2} \mathrm{CO}_{3}\right)$, gallic acid and catechol, aluminum chloride $\left(\mathrm{AlCl}_{3}\right)$ were purchased from Diamond Company, Cairo, Egypt. While, HPLC chemicals and standards were purchased from Sigma.

\section{Methods \\ Preparation of plant extracts:}

The dried plant material of each plant species was grounded into fine powder to pass $100 \mathrm{~mm}$ sieve. 200 grams of each plant powder were separately soaked in $1000 \mathrm{ml}$ of ethanol $95 \%$ and acetone with stirring for $48 \mathrm{~h}$, filtered through double layers of muslin, centrifuged at $9000 \mathrm{rpm}$ for $10 \mathrm{~min}$ and finally filtered again 
through Whatman filter paper No. (1) to attain a clear filtrate. The filtrates were evaporated and dried at $40^{\circ} \mathrm{C}$ under reduced pressure using rotatory vacuum evaporator. Finally, the extract was collected and stored in refrigerator at $4^{\circ} \mathrm{C}$ (Gauthami et al., 2015).

\section{Determination of total phenolics amounts in different extracts:}

The amounts of total phenolics in the studies extracts were determined with the Folin-Ciocalteu reagent. Gallic acid was used as a standard and the total phenolics were expressed as $\mathrm{mg}$ gallic acid equivalents (GAE)/g dry weigh. 0.5 $\mathrm{ml}$ of each sample and standard were introduced into test tubes and mixed with $2.5 \mathrm{ml}$ of a $\mathbf{1 0}$ fold dilute Folin-Ciocalteu reagent and $2 \mathrm{ml}$ of $7.5 \%$ sodium carbonate. The tubes were covered tightly and allowed to stand for $\mathbf{3 0} \mathrm{min}$ at room temperature before the absorbance which was read at $760 \mathrm{~nm}$ spectrometrically (Kim et al., 2003).

\section{Determination of total flavonoids amounts in different extracts:}

The total flavonoids contents were determined using the method reported by Dewanto et al., (2002). Briefly, an aliquot of $250 \mu \mathrm{l}$ of each extract or a standard solution was mixed with $1.25 \mathrm{ml}$ of deionized water followed by $75 \mu \mathrm{l}$ of a $5 \%$ $\mathrm{NaNO}_{2}$ solution. After $6 \mathrm{~min}, 150 \mu \mathrm{l}$ of $10 \% \mathrm{AlCl}_{3} \cdot 6 \mathrm{H}_{2} \mathrm{O}$ solution was added to each mixture. After $5 \mathrm{~min}, 0.5 \mathrm{ml}$ of $1 \mathrm{M}$ $\mathrm{NaOH}$ was added, and the total volume was adjusted to $3.0 \mathrm{ml}$ with deionized water. Catechin was used as a standard using absorbance at 510 enm for the measuring, which was corrected using a blank, the results were expressed as $\mathbf{m g}$ of catechin equivalents (CE)/g dry weight.

\section{Quantitative analysis of phenolic compounds by HPLC:}

HPLC analysis was analyzed at the Department of Food sciences, Faculty of
Agriculture, Cairo University. Phenolic compounds were fractionated and determined by HPLC according to the method of Goupy et al., (1999), by using HPLC Hewiletpckared (series 1050) equipped with auto-sampler injection, solvent degasser, Ultravilot (UV) detector set at $280 \mathrm{~nm}$ and quaternary HP pump (series 1050). Hewlett Packard using a column Alltima C18, 5mm (150 $\mathrm{mm} \times 4.6 \mathrm{~mm}$ Allech). The column temperature was maintained at $35^{\circ} \mathrm{C}$. Gradient separation was carried out with methanol and acetonitrile as a mobile phase at flow rate of $1 \mathrm{ml} / \mathrm{min}$. Standards were dissolved in a mobile phase and injected into HPLC. Retention time and peak area were used to calculate phenolic compounds concentration by the data of Hewllet packared software.

\section{Disc diffusion method:}

The antimicrobial activity was determined by the paper disc diffusion method using Mueller-Hinton agar plates (MHA) according to Baur et al., (1966). Discs of about $6 \mathrm{~mm}$ diameter were made from Whatman's No.1 filter paper using a paper puncher. Batches of 100 discs were transferred into Bijou bottles and sterilized in the oven at $121^{\circ} \mathrm{C}$ for 15 minutes. Stock solution $(400 \mathrm{mg} / \mathrm{ml})$ of the plant extract was prepared. Serial doubling dilution was carried out by adding $1 \mathrm{ml}$ of dimethylsulphoxide (DMSO) at each serial dilution. Four concentrations were prepared from the stock solution such that each disc absorbed $0.01 \mathrm{ml}$ which was equivalent to $50 \mathrm{mg} / \mathrm{ml}, 100 \mathrm{mg} / \mathrm{ml}, 200 \mathrm{mg} / \mathrm{ml}$ and $400 \mathrm{mg} / \mathrm{ml}$ respectively. The different concentrations of extracts $(50,100,200$ and $400 \mathrm{mg} / \mathrm{ml}$ ) were loaded on the $6 \mathrm{~mm}$ sterile individual discs. The loaded discs were placed on the surface of medium and the compound was allowed to diffuse for $5 \mathrm{~min}$ and the plates were kept for incubation at $37^{\circ} \mathrm{C}$ for $24 \mathrm{~h}$, at the end of incubation, inhibition zones formed 
around the disc were measured with transparent ruler in millimeter.

\section{Statistical analysis}

The data were subjected to statistical analysis using the SPSS (Software version no.20). Differences between extracts were tested by one-way analysis of variance (ANOVA). Probability value for the statistical test was $0.5 \%$. Also, Duncan test were used in order to compare the differences of the inhibition zones between control group with plants extracts (Turker et al., 2009)

\section{Results}

Total phenolics and total flavonoids contents in different plant extracts

Data in Fig. (1) showed that ethanolic extracts had the higher total phenolics content and total flavonoids content compared with acetone extracts in all both rosemary and thyme. Total phenolics content in ethanolic and acetone extracts of rosemary were 42.3 and $39.1 \mathrm{mg} / 100 \mathrm{~g}$, respectively, while total flavonoids content in the same extracts were 19.3 and $11.3 \mathrm{mg} / 100 \mathrm{~g}$, respectively. On the other hand, total phenolics content in thyme extracts has been ranged from 43.2 to $59.1 \mathrm{mg} / 100 \mathrm{~g}$, while total flavonoids content has been ranged from 19.8 to $20.4 \mathrm{mg} / 100 \mathrm{~g}$.

HPLC fractionation of ethanolic extracts in rosemary and thyme leaves

In rosemary extract nine compounds were detected, while in thyme extract twelve compounds were detected (Table 1). The major phenolic compound in rosemary extract was salicylic acid $(831.21 \mathrm{mg} / \mathrm{kg})$, while P- Hydroxy benzoic acid recorded the highest concentration $(96.14 \mathrm{mg} / \mathrm{kg})$ in thyme extract.

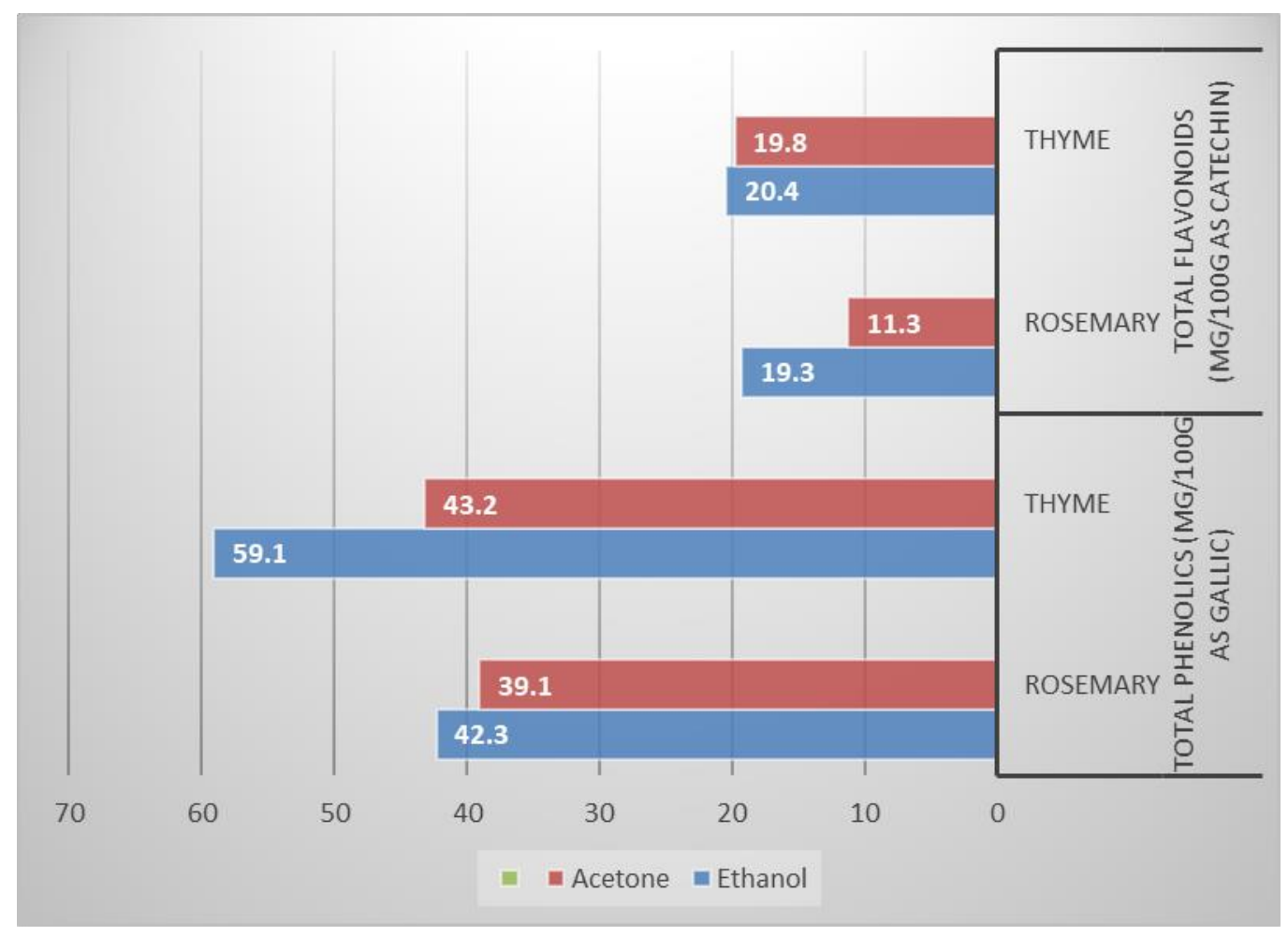

Fig. 1. Total phenolics and total flavonoids contents in different plant extracts. 
Table (1): HPLC analysis of phenolic compounds in rosemary and thyme ethanolic extracts.

\begin{tabular}{|c|c|c|}
\hline Phenolic compound $(\mathbf{m g} / \mathbf{K g})$ & Rosemary & Thyme \\
\hline Gallic acid & ND & 1.60 \\
\hline Catechol & ND & 43.64 \\
\hline P-Hydroxy benzoic acid & 195.01 & 96.14 \\
\hline Caffeine & ND & ND \\
\hline Vanillic acid & 25.36 & ND \\
\hline Caffeic acid & ND & 10.52 \\
\hline Syringic acid & 24.80 & 17.82 \\
\hline Vanillin & ND & 6.10 \\
\hline P-Coumaric acid & ND & 5.63 \\
\hline Ferulic acid & 149.22 & 4.05 \\
\hline Ellagic acid & 232.63 & 28.93 \\
\hline Benzoic acid & 302.70 & 45.36 \\
\hline O-Coumaric acid & 354.70 & 3.76 \\
\hline Salicylic acid & 831.21 & ND \\
\hline Cinnamic acid & 110.95 & 82.41 \\
\hline
\end{tabular}

ND = Non detected

Antibacterial effect of rosemary and thyme extracts against some food related bacteria

\section{1- Ethanolic extract}

The results in Fig. (2) showed that in all concentrations $(50,100,200$ and 400 $\mathrm{mg} / \mathrm{ml}$ ) of rosemary ethanolic extract exhibited the highest level inhibitory zone diameters (10.2, 14.3, 19.2 and 24 $\mathrm{mm}$, respectively) against Escherichia Coli, while the same extracts recorded the lowest level inhibitory zone diameters (5.3, 8.6, 11 and $15.3 \mathrm{~mm}$, respectively) against Staphylococcus aureus. Similarly, all concentrations $(50,100,200$ and $400 \mathrm{mg} / \mathrm{ml}$ ) of thyme ethanolic extract exhibited the highest level inhibitory zone diameters $(9.5,13.1,19.2$ and $24.1 \mathrm{~mm}$, respectively) against Escherichia coli, while the same extracts recorded the lowest level inhibitory zone diameters $(4.3,8.4,13.1$ and $17.1 \mathrm{~mm}$, respectively) against Bacillus cereus.

\section{2- Acetone extract}

The results in Fig. (3) showed that in all concentrations $(50,100,200$ and 400 $\mathrm{mg} / \mathrm{ml}$ ) of rosemary acetone extract exhibited the highest level inhibitory zone diameters (10.0, 13.4, 17.3 and 22.1 $\mathrm{mm}$, respectively) against Bacillus cereus, while the same extracts recorded the lowest level inhibitory zone diameters (5.1, 7.4, 10.2 and $14.2 \mathrm{~mm})$ against Staphylococcus aureus. On the other hand, acetone extracts of thyme $(50,100$, 200 and $400 \mathrm{mg} / \mathrm{ml}$ ) exhibited the highest level inhibitory zone diameters $(10,14.2$, 19.1 and $24.2 \mathrm{~mm}$, respectively) against Salmonella typhi, while the same extracts recorded the lowest level inhibitory zone diameters (4.9, 8.2, 11.3 and $16.3 \mathrm{~mm}$ ) against Escherichia coli.

\section{Discussion}

Researchers have consistently reported the need to search for bacterial 
antibiotic resistance modifying agents that could positively alter the efficacy of one or more clinically relevant antibiotics to inhibit resistant pathogenic bacteria (Diniz-Silva et al., 2017). In contrast, plant extracts are less likely to generate antimicrobial resistance owing to the wide variety of their active compounds, therefore they could reverse the antibiotic resistance and minimize the exposure of humans to resistant bacteria (Gupta and Birdi, 2017).

Dietary polyphenols present structural features of phenolics and constitute one of the most numerous and widely distributed group of natural compounds in the plant kingdom (Abbas et al., 2017). So far, over 8000 phenolic structures have been recognized, and more than a half of which have been identified as flavonoids (Oliver et al., 2016).

The results of the current study indicate that the different extracts (Ethanol and acetone) of the rosemary and thyme contain large quantities of total phenolics and total flavonoids (Fig.1).

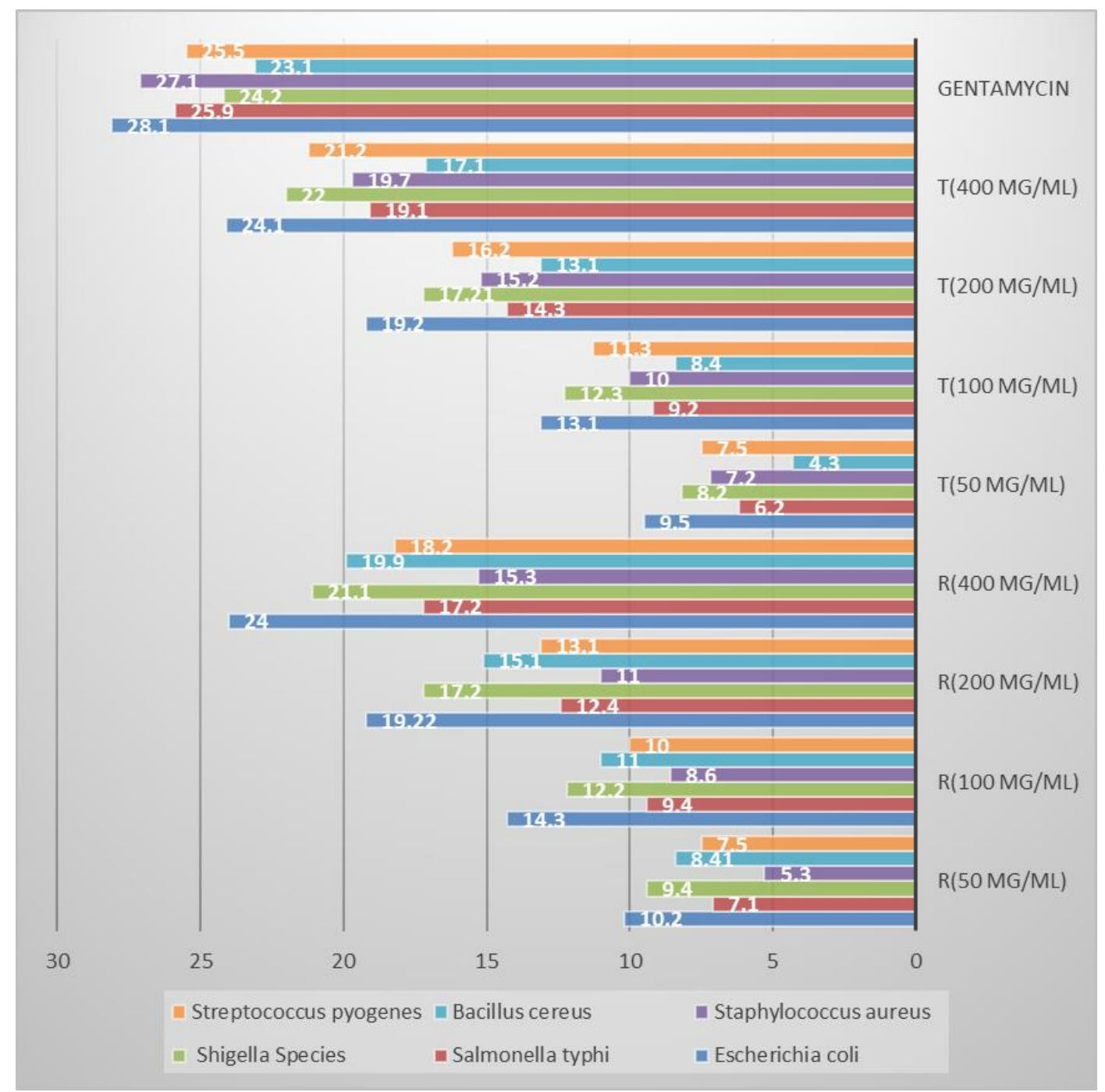

$R=$ Ethanolic extract of rosemary, $T=$ Ethanolic extract of thyme.

Fig. 2. Inhibition zone diameter of rosemary and thyme ethanolic extracts against some food related bacteria 


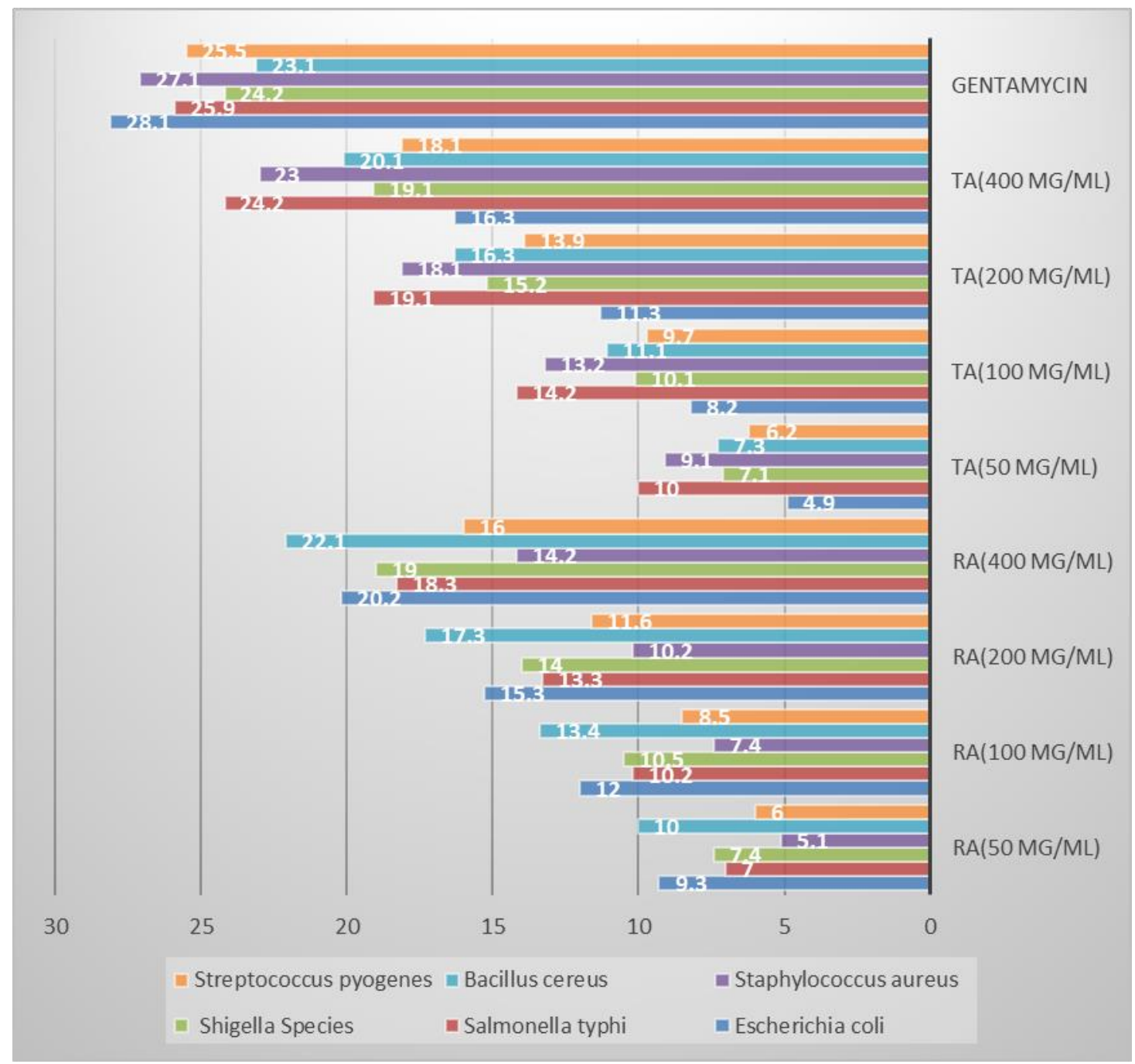

$\mathrm{RA}=$ Acetone extract of rosemary, $\mathrm{TA}=$ Acetone extract of thyme.

Fig. 3. Inhibition zone diameter of rosemary and thyme (acetone extracts) against some food related bacteria

Overall, polyphenols are a highly diverse group of compounds with several subgroups that may widely differ in their stability, bioavailability, and physiological functions (Tsao, 2010). Polyphenols may exhibit an important antimicrobial activity, the mechanisms of which have not been completely recognized yet (Tomadoni et al., 2016). The known mechanisms include the capability for modifying cell membranes permeability, the changes in several intracellular functions caused by the phenolics to enzymes binding or by the loss of the cell wall integrity due to various interactions with the cell membrane (Bouarab-Chibane et al., 2019).

From the above came the idea of using rosemary and thyme extracts as natural antimicrobials that cause food spoilage and those that cause some diseases to humans, because these plants contain many secondary metabolites, that are effective in eliminating harmful microorganisms.

Several studies have reported plant extracts rich in polyphenols to be capable of inhibiting the growth of 
spoilage bacteria and fungi and have suggested their utility in the food industry (Daglia, 2012; Tehranifar et al., 2011; Tomadoni et al., 2016). It is also believed that individual phytochemicals do not work as effectively as heterogeneous extracts (Seow et al., 2014). This is important, since concerns have been raised about the growing number of foodborne outbreaks caused by pathogens associated with the high rate of antibiotic resistance (Alejo-Armijo et al., 2018).

Results of published literature also indicate that the main mechanism underlying the antibacterial effects of polyphenols potentially involve damage to the bacterial membrane, with changes in permeability and to bind with bacterial cell walls and prevent cell division and growth (Cowan, 1999; El Sohaimy, 2014).

For example, Gram-negative bacteria were reported to be resistant toward many antibacterial substances, due to the hydrophilic surface of their outer membrane and associated enzymes in the periplasmic space, which are capable of breaking down many molecules introduced from outside (Gao et al.,1999; Shan et al., 2007). However, the results of this study revealed that the tested Gramnegative pathogens (Escherichia coli, Salmonella typhi and Shigell Species) have varying degrees of antimicrobial susceptibility against natural phenolics. Some authors have suggested that the loss of structural integrity and the ability of the membrane to act as a permeability barrier was due to the damage to the cell wall and cytoplasmic membrane (Cueva et al., 2010; Shan et al., 2007). The distortion of the cell physical structure could expand and destabilize the membrane and increase membrane fluidity, which results in increased permeability (Gyawali and Ibrahim, 2014) and leakage of various vital intracellular constituents, such as ions, ATP, nucleic acids, and amino acids (Lambert et al., 2001; Shan et al., 2007). It should be noted that the phenolic compounds might bind to the cell surface and then penetrate to the target sites, possibly the phospholipid bilayer of the cytoplasmic membrane and membrane-bound enzymes (Gyawali and Ibrahim, 2014).

\section{Conclusion}

The results of the current study showed that the ethanol and acetone extracts of rosemary and thyme plants contain good amounts of total phenolics and total flavonoids. These extracts also showed a significant effect against bacterial strains that cause food spoilage as well as pathogenic to humans used in the experiment, which indicates the possibility of using these extracts as natural anti-bacterial agents in the face of the increasing trend of bacteria to resist antibiotics.

\section{REFERENCES}

Abbas, M., F. Saeed, F.M. Anjum, M. Afzaal, T. Tufail and M.S. Bashir (2017). Natural polyphenols: An overview. International Journal of Food Properties. 20(8): 1689-1699.

Aguilar, F., H. Autrup, S. Barlow, L. Castle, R. Crebelli, W. Dekant, K.H. Engel, N. Gontard, D. Gott and S. Grilli (2008). Use of rosemary extracts as a food additive-scientific opinion of the panel on food additives, flavourings, processing aids and materials in contact with food. EFSA J. 721: 1-29.

Ahameethunisa, A.R. and W. Hooper (2010). Antibacterial activity of Artemisia nilagirica leaf extracts against clinical and phytopathogenic bacteria.BMC Complementary and Alternative Medicine 10: 1-6.

Alejo-Armijo, A., N. Glibota, M.P. Frias, J. Altarejos, A. Galvez and S. Salido (2018). Synthesis and evaluation of antimicrobial and antibiofilm 
properties of A-type procyanidin analogues against resistant bacteria in food. Journal of Agricultural and Food Chemistry: 66(9): 2151-2158.

Banso, A. (2009). Phytochemical and antibacterial investigation of bark extracts of Acacia nilotica. J. Med. Plants Res. 3(2): 82-85.

Baur, A.W., W.M.M. Kirby and M. Turk (1966). Antibiotic susceptibility testing by a standardized single disk method. Am. J. clin. Patho. 45(4):493 - 496.

Boruga, O., C. Jianu, C. Misca, I. Golet, A.T. Gruia and F.G. Horhat (2014). Thymus vulgaris essential oil: chemical composition and antimicrobial activity. J Med Life. 7(3): 56-60.

Bouarab-Chibane, L., V. Forquet, P. Lanteri, Y. Clement, L. Leonard-Akkari and N. Oulahal (2019). Antibacterial properties of polyphenols: Characterization and QSAR (Quantitative Structure-Activity Relationship) models. Frontiers in Microbiology. 10:829.

Centers for Disease Control and Prevention (2013). Antibiotic Resistance Threats in the United States.

Cowan, M. M., (1999). Plant products as antimicrobial agents. Clin. Microbiol., 12: 564-582.

Cueva, C., M.V. Moreno-Arribas, P.J. Martín-Álvarez, G. Bills, M.F. Vicente, A. Basilio, C.L. Rivas, T. Requena, J.M. Rodríguez and B. Bartolomé (2010). Antimicrobial activity of phenolic acids against commensal, probiotic and pathogenic bacteria. Res. Microbiol. 161: 372-382.

Daglia, M. (2012). Polyphenols as antimicrobial agents. Current Opinion in Biotechnology: 23(2): 174-181.

Dewanto, V., X. Wu, K.K. Adom and R.H. Liu (2002). Thermal processing enhances the nutritional value of tomatoes by increasing total antioxidant activity. J. Agric. Food Chem.50 (10): 3010- 3014.

Diniz-Silva, H.T., M. Magnani, S. de Siqueira, E.L. de Souza and J.P. de Siqueira Junior (2017). Fruit flavonoids as modulators of norfloxacin resistance in Staphylococcus aureus that overexpresses norA, LWT - Food Sci. Technol. (Lebensmittel-Wissenschaft - Technol.). 85: 324-326.

Djenane, D., A. Sánchez-Escalante, J.A. Beltrán and P. Roncalés (2002). Ability of $\alpha$-tocopherol, taurine and rosemary, in combination with vitamin $\mathrm{C}$, to increase the oxidative stability of beef steaks displayed in modified atmosphere. Food Chem. 76: 407-415.

Djeussi, D.E., J.A.K. Noumedem, J.A. Seukep, A.G. Fankam, I.K. Voukeng, S.B. Tankeo, H.L. Antoine, A.H.L. Nkuete and A. Victor Kuete (2013). Antibacterial activities of selected edible plants extracts against multidrug-resistant Gram-negative bacteria. BMC Complementary and Alternative Medicine. 13: 164.

EI Sohaimy, S.A. (2014). Chemical composition, antioxidant and antimicrobial potential of artichoke. The Open Nutraceuticals J.7: 15-20.

Gao, Y., M.J. van Belkum and M.E. Stiles (1999). The outer membrane of Gramnegative bacteria inhibits antibacterial activity of brochocinc. Applied and Environmental Microbiology. 65: 4329-4333.

Garau, I. (1994). Beta-lactamases: Current situation and clinical importance. Intensive care medicine. 20:55-59.

Gauthami, M., N. Srinivasan, M.G. Neelam, K. Boopalan and K. Thirumurugan (2015). Synthesis of Silver Nanoparticles using Cinnamomum zeylanicum Bark Extract and its Antioxidant 
Activity. Nano Sci. Nanotech. Asia. 5(1): 2-7.

Goupy, P., M. Hugues, P. Biovin and M.J. Amiot (1999). Antioxidant isolated phenolic compounds. J. Sci. Food Agric. 79:1625 -1634.

Gupta, P. D. and T. J. Birdi (2017). Development of botanicals to combat antibiotic resistance. Journal of Ayurveda and Integrative Medicine. 8: 266-275.

Gyawali, R. and S.A. Ibrahim (2014). Natural products as antimicrobial agents. Food Control. 46: 412-429.

Iwu, M.W., A.R. Duncan and C.O. Okunji (1999). New antimicrobials of plant origin. J. Janick, Ed., ASHS Press, Alexandria, Virginia. p. 457 - 462.

Jabeen, R., M. Ashraf and I. Ahmad (2007). Evaluating the effects of cold water diffusates against Xanthomonas oryzae Pv. Oryzae causing bacterial leaf blight in rice. Archives of Phytopathology and Plant Protection. 42 (2): 173- 187.

Kim, D.O., S.W. Jeong and C.Y. Lee (2003). Antioxidant capacity of phenolic phytochemicals from various cultivars of plums. Food Chem.81(3): 321-326.

Lambert, R.J.W., P.N. Skandamis, P.J. Coote and G.J.E. Nychas (2001). A study of the minimum inhibitory concentration and mode of action of oregano essential oil, thymol and carvacrol. J. Appl. Microbiol. 91: 453462.

Laxminarayan, R. (2003). Battling resistance to antibiotics and pesticides: an economic approach. Washington, DC: Resources for the Future.

Manconi, M., G.L. Petretto, G. D'Hallewin, E. Escribano, E. Milia, R. Pinna, A. Palmieri, M. Firoznezhad, J.E. Peris and I. Usach (2018). Thymus essential oil extraction, characterization and incorporation in phospholipid vesicles for the antioxidant/antibacterial treatment of oral cavity diseases. Colloids Surf. B: Biointerfaces. 171: 115-122.

Murugesan, S., A. Pannerselvam and A.C. Tangavelou (2011). Phytochemical screening and antimicrobial activity of the leaves of Memecylon umbellatum burm. F. Journal of Applied Pharmaceutical Science. 1(1): 42-45.

Negi, P.S. (2012). Plant extracts for the control of bacterial growth: Efficacy, stability and safety issues for food application. Int. J. Food Microbiol. 156: 7-17.

Nieto, G., P. Díaz, S. Bañón and M.D. Garrido (2010). Dietary administration of ewe diets with a distillate from rosemary leaves (Rosmarinus officinalis L.): Influence on lamb meat quality. Meat Sci. 84: 23-29.

Nieto, G., S. Bañon and M.D. Garrido (2012). Incorporation of thyme leaves in the diet of pregnant and lactating ewes: Effect on the fatty acid profile of lamb. Small Rumin. Res. 105: 140-147.

Oliver, S., O. Vittorio, G. Cirilloe and C. Boyer (2016). Enhancing the therapeutic effects of polyphenols with macromolecules. Polymer Chemistry. 7: 1529-1544.

Savoia, D. (2012). Plant-derived antimicrobial compounds: alternatives to antibiotics. Future Microbiol. 7: 979-990.

Seow, Y.X., C.R. Yeo, H.L. Chung and H.G. Yuk (2014). Plant essential oils as active antimicrobial agents. Critical Reviews in Food Science and Nutrition. 54(5): 625-644.

Shan, B., Y.Z. Cai, J.D. Brooks and H. Corke (2007). Antibacterial properties and major bioactive components of cinnamon stick (Cinnamomum burmannii): activity against foodborne 
pathogenic bacteria. Journal of Agricultural and Food Chemistry. 55: 5484-5490.

Tajkarimi, M.M., S.A. Ibrahim and D.O. Cliver (2010). Antimicrobial herb and spice compounds in food. Food Control. 21: 1199-1218.

Tehranifar, A., Y. Selahvarzi, M. Kharrazi and V. J. Bakhsh (2011). High potential of agro-industrial by-products of pomegranate (Punica granatum L.) as the powerful antifungal and antioxidant substances. Industrial Crops and Products. 34(3): 1523-1527.

Tomadoni, B., G. Viacava, L. Cassani, M. R. Moreira and A. Ponce (2016). Novel biopreservatives to enhance the safety and quality of strawberry juice.
Journal of Food Science and Technology:53(1): 281-292.

Tsao, R. (2010). Chemistry and biochemistry of dietary polyphenols. Nutrients. 2: 1231-1246.

Turker, H., A. B. Yildirım and F. P. Karakaş (2009). Sensitivity of bacteria isolated from fish to some medicinal plants. Turkish journal of Fisheries and Aquatic Sciences, 9: 181-186.

World Health Organization (WHO) (2002). Traditional Medicine Strategy. Geneva. PP.55-58.

World Health Organization (WHO) (2007). Fact sheet No. 237:"Food safety and foodborne illness". 
W. S. Abd El Kader, et al.,

تقييم التأثير المضد لنمو الميكروبات لمستخلصات الزعتر وإكليل الجبل في مكافحة بعض أنواع البكتريا الموجودة في الأغذية

وليد صلاح عبد القادر(')، عبد العزيز علي صقر (r)، خالد مأمون طه(r)،

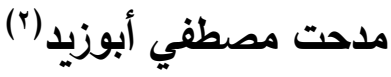

(1) (1) وزارة الصحة وإلسكان

(ץ) قسم الكيمياء الحيوية - كلية الزراعة - جامعة المنوفية المانة

الملخص العربى

يؤدي الاستخدام المتزايد للمضادات الحيوية إلى ظهور نمو سلالات مقاومة. بالاضافه الى ذلك نحن نواجه نقصًا في

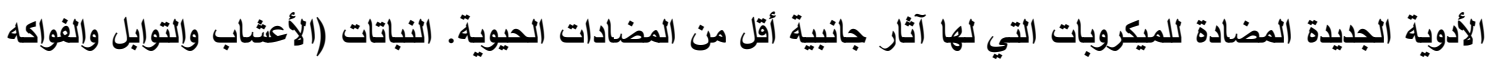
والخضروات والبذور والأولق) هي المصدر الرئيسي لبصض النواتج الثانويه التى يمكن استخدامها كمضادادات الميكروبات.

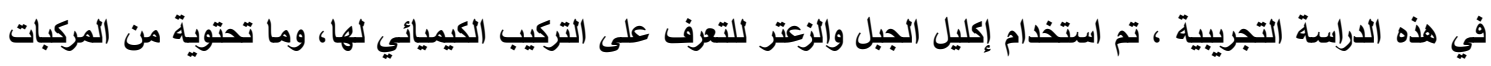

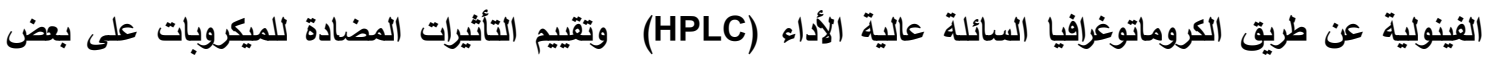

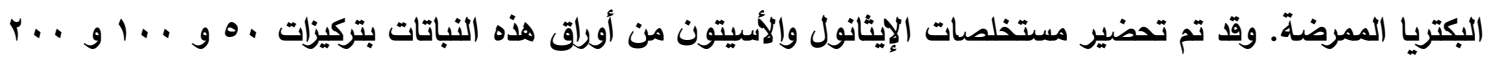

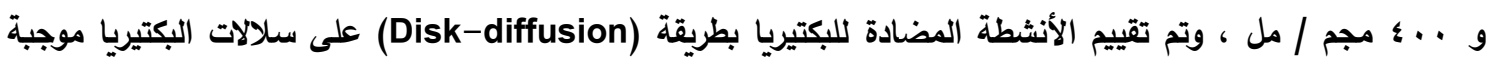
الجرام: Staphylococcus aureus, Bacillus cereus and Streptococcus pyogene الجرام: Escherichia coli, Salmonella typhi and Shigella species وقد أظهرت النتائج أن جميع تراكيز مستخلصات الإيثانول والأسيتون لإكليل الجبل أعطت أعلى مستوى تثبيط ضد Escherichia coli and Bacillus cereus بينما سجلت نفس المستخلصات أقل مستوى تثبيط ضد Staphylococcus aureus كلا المستخلصين. وبالمثل أظهرت جميع تراكيز مستخلصات الإيثانول والأسيتون للزعتر أقصى تثبيط ضد تئد

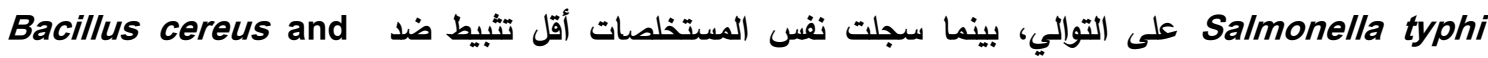
Escherichia coli في الأغذية للتفلب علي ظاهرة مقاومة البكتريا للمضادات الحيوية والتي تمثل تحديا خطيرا أمام الجنس البشري.

$$
\begin{aligned}
& \text { أسماء السادة المحكمين } \\
& \text { استاذ الكيمياء الحيوية كلية الزراعة - جامعة الزقازيق } \\
& \text { استاذ ورئيس قسم الكيمياء الحيوية، كلية الزراعة، جامعة المنوفية }
\end{aligned}
$$

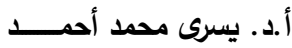

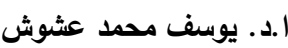

